\title{
INFLUENCE OF VITAMIN E AND SELENIUM SUPPLEMENTATION ON THE PERFORMANCE, REPRODUCTIVE INDICES AND METABOLIC STATUS OF OSSIMI EWES
}

\author{
Sherief M. Abdel-Raheem ${ }^{1 *}$, G. B Mahmoud², Waleed Senosy³, Taymour M. El-Sherry ${ }^{4}$
}

${ }^{1}$ Department of Animal Nutrition and Clinical Nutrition, Faculty of Veterinary Medicine, Assiut University, 71526, Egypt, ${ }^{2}$ Department of Animal production, Faculty of Agriculture, Assiut University, ${ }^{3}$ Department of Theriogenology, Faculty of Veterinary Medicine, New Valley University, 51714, Egypt, ${ }^{4}$ Department of Theriogenology, Faculty of Veterinary Medicine, Assiut University

*Corresponding author, E-mail: sherief.diab@aun.edu.eg

\begin{abstract}
The objective of this study was to investigate the effects of pre and post-lambing intramuscular (i.m.) injections of vitamin E (VE) and selenium (Se) on the performance, reproductive indices and metabolic status of Ossimi ewes. A total of 20 pregnant ewes were divided randomly into two equal groups of ten animals. The control group (CG) was administered $3 \mathrm{ml}$ of normal saline. The treated group (TG) was administered a combination of $5 \mathrm{mg}$ of sodium selenite and $450 \mathrm{mg}$ of VE twice weekly for 2 weeks pre and post lambing. The performance, reproductive indices, colostrum and milk mineral profiles, blood metabolites and antioxidant enzyme biomarkers were investigated in this experiment. VE and Se supplementation had a significant effect on ewe, lamb performance, colostrum and milk mineral profiles. The treated ewes lost less weight $(0.7 \mathrm{~kg})$ compared with the ewes in the control group $(3.68 \mathrm{~kg})$ on $30^{\text {th }}$ day postpartum $(P<0.001)$. Lambs born to treated ewes were heavier than those born to control ewes $(4.47 \mathrm{~kg}$ vs $3.99 \mathrm{~kg}$, respectively), gained more daily weight quickly (268.66 vs. $226.00 \mathrm{~g}$, respectively, $\mathrm{P}<0.001)$ and weighed more on $30^{\text {th }}$ day post-lambing (12.53 vs. $10.77 \mathrm{~kg}$, respectively, $\mathrm{P}<0.001)$. Treated ewes had higher concentrations of blood glucose, total protein, total cholesterol, antioxidant enzyme biomarkers, and lower concentrations of serum non-esterified fatty acids (NEFA). VE and Se supplementation had a significant effect $(\mathrm{P}<0.05)$ on postpartum reproductive performance of ewes in terms of fast uterine involution, earlier resumption of ovarian function and ovulation with large size ovulatory follicles, and greater numbers of small, medium, and large-sized follicles. In conclusion, VE and Se supplementation during late gestation and early lactation could be considered an effective strategy for minimizing the weight loss of ewes, enhancing lamb performance, the antioxidant and metabolic status, which improves the reproductive performance of Ossimi ewes.
\end{abstract}

Key words: vitamin E; selenium; lamb performance; reproductive performance; antioxidant status; Ossimi ewes

\section{Introduction}

Over the last decade, ewe fertility has been progressively deteriorating around the world. 
Improving productivity by improving the peripartum period has become an important problem. Ewes are often deficient in certain trace elements and vitamins important for lambing because they graze on dry pastures of poor-quality during pregnancy, which can influence lamb survival, birth weight, subsequent poor animal production and welfare (1). Vitamins and minerals play an important role in the growth, physiology, and reproductive performance of animals. Se deficiency is linked to several reproductive disorders of cattle including abortion, retained placenta, neonatal weakness, metritis, poor uterine involution, cystic ovaries, impaired fertilization of ova, impaired fertility, and repression of immunity $(2,3)$. Selenium (Se) and vitamin E (VE) both prevent oxidative degeneration of biological membranes. Vitamin $E$ and the Se-containing enzyme glutathione peroxidase (GSHpx) are critical components of the antioxidant system that functions in all cells (4). Vitamin E and Se are integral parts of the antioxidant defense system and participate in critical enzymatic reactions, which directly influence growth performance, function of the immune system, and reproductive performance of animals $(5,6)$. Newborns are likely to experience VE deficiency; due to the insignificant amount of VE transmitted to the fetus in the uterus, it is important that colostrum must supply enough VE to the lamb (7). Ewes that were supplemented with VE and Se during late gestation gave birth to heavier lambs with reduced mortality as compared to lambs born to nonsupplemented ewes $(8,9)$. Although fresh grass contains high amount of VE, the amount of VE decreases during storage and conservation and depends on forage species and time of harvest (7). The previous National Research Council (NRC, 1985) (10) recommendation of 15 IU of VE/kg dry matter (DM) was increased by approximately 17-times in the NRC's most recent set of recommendations (2007) (11) to increase the immunocompetence of animals. However, it has not been fully documented that VE and Se supplementation of ewes has a beneficial synergistic effect on reproductive and productive lamb performance. Therefore, the objective of this study was to investigate the effect of pre and post lambing intramuscular (i.m.) injections of VE and Se on the performance, reproductive indices and metabolic status of Ossimi ewes

\section{Material and methods}

The study was performed according to the regulations and procedures approved by the Ethics Committee on Animal Experimentation of Assiut University, Faculty of Veterinary Medicine and the Guide for the Care and Use of Laboratory Animals (National Institute of Health publication no. 8023, revised 1978).

\section{Experimental site}

The study period was the winter breeding season from December to February. The ambient temperature ranged from $21.6-26^{\circ} \mathrm{C}$ while the relative humidity was ranged from $50-54 \%$. Ewes were kept indoors at the Research and Production Farm, Department of Animal Production, Faculty of Agriculture, Assiut University (latitude $28^{\circ} 07^{\prime} \mathrm{N}$ and $30^{\circ} 33^{\prime} \mathrm{E}$ ).

\section{Animals, management, and treatments}

A total of 20 pregnant Ossimi ewes (identified by ultrasonography) were used of nearly similar age (4-5 years), with 1-2 parity and their average weight of $53.86 \mathrm{~kg}$. Two weeks prior to anticipated lambing, healthy ewes clinically free from external and internal parasites were selected for the present study. Each ewe had free access to food and water and was maintained in an individual pen. Ewes were fed a late pregnancy diet (Table 1) until a parturition lactation diet was offered. Ewes were divided into two equal groups of 10 animals. The control group (CG) received no supplementation and administered $3 \mathrm{ml}$ of normal saline. The treated group (TG) received an injection of $\mathrm{VE}$ and $\mathrm{Se}$ (3 ml i.m. from Viteselen $15^{\circledR}$, Adwia Company, Egypt). Each ewe in the TG was injected with $5 \mathrm{mg}$ of sodium selenite and $450 \mathrm{mg} \mathrm{VE}$ twice weekly for two weeks pre and post lambing; lambing occurred over a two week period. Food was mixed daily and ewes were fed two times a day. All nutrients met or exceeded the requirements for $60 \mathrm{~kg}$ ewe at the last four weeks of gestation and ewes at the first 6-8 weeks of lactation, according to guidelines 
from the National Research Council for sheep (NRC, 1985). The late pregnancy diet consisted of $70 \%$ Berseem hay and $30 \%$ concentrate mixture. The lactation diet consisted of $40 \%$ Berseem hay and $60 \%$ concentrate mixture along with wheat straw offered ad libitum (Table 1). For both groups, the experimental diet contained approximately $0.38 \mathrm{ppm}$ Se and 23 $\mathrm{mg} \mathrm{VE} / \mathrm{kg}$ diet. Two meals of equally allotted feed were given to all ewes at 08:00 and 17:00 and leftover feed was removed and weighed. The amount of feed consumed daily was recorded and representative samples were subjected to chemical analysis.

\section{Ovarian and uterine examinations}

Sonographic examinations were performed on postpartum days $2,4,6,8,11,14,17$, and 25 using a real-time B-mode ultrasound scanner (Pie Medical, 100 LC, Holland) with a line array transducer of 5.0 MHz. Ovarian examination was carried out by ultrasonography to monitor follicular growth, ovulation, and corpus luteum formation. Uterine involution was investigated by measuring the maximal transversal cross-sectional diameter and the lumen diameter of both the right and left uterine horns. Furthermore, the presence and echogenicity of uterine cavity contents were included in this investigation. Entire follicles of $3 \mathrm{~mm}$ in diameter or greater were recorded. The term wave was defined as one or more antral follicles growing 3 to $\geq 5 \mathrm{~mm}$ in diameter before regression.

\section{Blood sampling and estimation of biochem- ical parameters and steroid hormones}

Blood samples were collected from the jugular vein parallel to sonographic examination. Duplicate blood samples were collected per animal, which were subjected to centrifugation at $3000 \mathrm{rpm}$ for $20 \mathrm{~min}$. Following centrifugation, plasma was harvested and stored at $-20{ }^{\circ} \mathrm{C}$ prior to testing. A colorimetric method was used to evaluate the blood metabolites (glucose, total protein, triglycerides, total cholesterol, AST, and ALT) using kits from Spinreact ${ }^{\circledR}$ Company (Spain). A direct ELISA was used to determine concentrations of progesterone (P4) (Diagnostic System Laboratory Co. (DSL),
USA, catalogue no. 3900). The intra- and interassay coefficient of variation for estrogen and progesterone was $3.6 \%$ and $12.43 \%$, respectively. The sensitivity of the assay for P4 was $0.12 \mathrm{ng}$.

\section{Determination of oxidant and antioxidant levels}

The levels of the oxidant (malondialdehyde (MDA); catalog no. MAK085, Sigma-Aldrich, USA), the antioxidant (reduced glutathione (GSH); catalog no. RS505, Randox Laboratories Ltd, UK) and total antioxidant capacity (TAC) (catalog no. NX2332, Randox Laboratories Ltd, UK) were determined by a colorimetric method using kits according to the instructions provided by the manufacturer's (SigmaAldrich, USA and Randox Laboratories Ltd, UK).

Plasma and milk concentrations of trace elements

A flame atomic absorption spectrophotometer (Shimadzu, AA-7000, Japan model) was used to measure $\mathrm{Cu}$ and $\mathrm{Zn}$ levels in colostrum and milk according to the procedure described by El-Bahr and Abdelghany (12). A graphite furnace (GFA-EX7) atomic absorption spectrophotometer (Shimadzu, Koyoto, Japan) was used to measure Se. Sample digestion was performed according to Official Methods of Analysis of AOAC (13). The graphite furnace program for measuring Se by GFA-EX7 and instrument settings were similar to those previously described by Meligy (14).

\section{Statistical analysis}

SPSS software (SPSS analytical program for windows version 16; SPSS) (15) was used to conduct the statistical analyses. Independent ttest was used to detect the significant differences in the treatment means of estrus onset, estrus duration, time of ovulation, emergence of ovulatory follicles, maximum size of ovulatory follicles, and blood metabolites. The effect of time on each variable in each group was evaluated using analysis of variance with repeated measurements of the general linear model using the Bonferroni multiple comparison test. Prob- 
ability values less than $0.05(\mathrm{P}<0.05)$ were considered significant. Results are presented as mean \pm SE.

\section{Results}

\section{Lamb and ewe performance}

There was a significant improvement in lamb performance of $\mathrm{TG}$ in terms of heavier birth weight and higher weight gain at 30 days post-partum (Table 2). Similarly, there was a significant improvement in ewe body weight of TG at the time of lambing and 30 days post-partum.

\section{Postpartum uterine involution}

The rate of uterine involution was significantly faster $(\mathrm{P}<0.05)$ in the $\mathrm{TG}$ compared with the control group at 6 and 11 days post-lambing (Figure 2). Uterine diameter was smaller in the TG than that of the $\mathrm{CG}$ on days $4,6,8$, and 11 postpartum while there were no differences between both groups on day 14, 17, 20, and 25 postpartum (Figure 2).

\section{Postpartum ovarian resumption}

The first ovulation and ovarian resumption occur earlier in TG compared with CG. As confirmed by the recorded first elevation in progesterone (P4) postpartum that was coincided with ultrasonic lutein tissue on the ovarian surface was at $16.7 \pm 1.0$ days in treated ewes, which was significantly earlier $(\mathrm{p}<0.01)$ compared with the CG $(25.7 \pm 1.0$ days $)$. This result indicates that the first ovulation and ovarian resumption occurred earlier in the treated group compared with CG. The size of the first ovulatory follicle was larger $(\mathrm{P}<0.05)$ in the TG $(6.6$ $\pm 0.02 \mathrm{~mm})$ in comparison with the $\mathrm{CG}(5.8 \pm$ $0.03 \mathrm{~mm})$. Moreover, progesterone concentration at that time was $1.4 \pm 0.08 \mathrm{ng} / \mathrm{ml}$ and $1.1 \pm$ $0.07 \mathrm{ng} / \mathrm{ml}$ for the TG and CG, respectively. The number of small follicles was higher $(\mathrm{P}<0.05)$ in the TG at different times during the postpartum period (Fig. 2, A). The overall number of small follicles during the study period was higher $(\mathrm{P}<0.001)$ in the TG (Fig. 2, D). The number of medium sized follicles fluctuated during the study period but was higher in the TG (Fig 2, B). In addition, the overall number of medium-sized follicles was high $(\mathrm{P}<0.01)$ in treated ewes compared with the CG (Fig. 2, D). The number of large follicles was higher in the TG $(\mathrm{P}<0.05)$ during different intervals of the postpartum period (Fig. 2, C). However, the overall number of large follicles did not differ between both groups during the study period (Figure 2, D).

\section{Metabolic and biochemical profiles}

The concentration of glucose in blood ( $\mathrm{mg} / \mathrm{l})$ was higher in the treated ewes $(\mathrm{P}<0.05)$ in comparison with the control during the early postpartum period until day 20 postpartum (Figure 3 , A). Similarly, total protein $(\mathrm{g} / \mathrm{l})$ was higher in the TG $(\mathrm{P}<0.05)$ on day $2,4,8,14,17$, and 20 postpartum. Furthermore, the concentration of total cholesterol $(\mathrm{mg} / \mathrm{dl})$ was higher in the treated ewes during the postpartum period of the study. The concentration of non-esterified fatty acids (NEFA; mmol/l) significantly elevated $(\mathrm{P}<0.05)$ in the $\mathrm{CG}$ during the postpartum period except at day 6 postpartum as compared to the CG. The concentration of triglycerides $(\mathrm{mg} / \mathrm{dl})$ was higher $(\mathrm{P}<0.05)$ at day 2 and day 6 postpartum than control while it lowered during days 17,20 and 25 postpartum in the treated ewes.

\section{Antioxidant enzyme biomarkers and sele- nium concentrations}

The MDA concentration (mmol/l) was higher $(\mathrm{P}<0.05)$ in control ewes compared with the treated ones during the postpartum period (Table 3). The blood concentration of TAC was significantly higher $(\mathrm{P}<0.05)$ in the TG at days 2,4 and numerically not statistically on days 14 , 17,20 , and 25 compared to the CG. In addition, plasma levels of reduced $\mathrm{GSH}(\mathrm{U} / \mathrm{g} \mathrm{Hb})$ were significantly higher on days $4,14,17,20$, and 25 in the TG compared with the CG. The concentration of Se $(\mu \mathrm{mol} / \mathrm{L})$ in serum was significantly higher in the TG on days $2,4,14,17,20$, and 25 compared with the CG.

\section{Trace element profile in colostrum and milk}

The data exhibited in table 4 revealed that the concentrations (ppm) of copper and $\mathrm{Se}$ in colostrum and milk were significantly $(p<0.05)$ higher in the TG. However, the concentration 
of zinc $(\mathrm{ppm})$ in the colostrum and milk har- icantly $(\mathrm{P}<0.05)$ than those of CG. vested from treated ewes was decreased signif

Table 1: Ingredients and analyzed chemical composition of experimental diets during pregnancy and early lactation (as fed basis)

\begin{tabular}{|c|c|c|}
\hline Item & Late pregnancy diet & Early lactation diet \\
\hline \multicolumn{3}{|l|}{ Ingredient, \% } \\
\hline Concentrate mixture & 30 & 60 \\
\hline Berseem hay & 70 & 40 \\
\hline Wheat straw & Ad libitum & Ad libitum \\
\hline Total & 100 & 100 \\
\hline \multicolumn{3}{|l|}{ Concentrate mixtures, $\%$} \\
\hline Ground yellow corn & 75.7 & 75.7 \\
\hline Soybean meal (44\%) & 3 & 15 \\
\hline Wheat bran & 19 & 7 \\
\hline Vitamin and mineral Premix ${ }^{*}$ & 0.3 & 0.3 \\
\hline Limestone & 1.5 & 1.5 \\
\hline Salt & 0.5 & 0.5 \\
\hline Total & 100 & 100 \\
\hline \multicolumn{3}{|c|}{ Chemical composition (\%, unless stated) } \\
\hline Dry matter & 87.67 & 87.42 \\
\hline ME Mcal/head/day** & 3.67 & 5.47 \\
\hline Crude protein & 13.00 & 14.00 \\
\hline Crude fiber & 20.11 & 12.81 \\
\hline Crude Fat & 2.46 & 2.38 \\
\hline Nitrogen free extract & 41.02 & 49.74 \\
\hline Ash & 11.08 & 8.49 \\
\hline Organic matter & 76.59 & 78.93 \\
\hline Calcium & 1.00 & 0.84 \\
\hline Phosphorus & 0.30 & 0.30 \\
\hline Selenium, $\mathrm{mg} / \mathrm{kg}$ & 0.38 & 0.38 \\
\hline Vitamin E, mg/kg & 23.00 & 23.00 \\
\hline
\end{tabular}

*Vitamin and mineral premix each 3 kg contain: 1250000 IU Vit. A; 2500000 IU Vit. D3; $1000 \mathrm{mg}$ Vit E; 80000 mg Mn; $60000 \mathrm{mg} \mathrm{Zn;} 50000$ iron, 20000 copper, 5000 iodine, $250 \mathrm{Se}, 1000 \mathrm{Co} \mathrm{mg}$ tell $3 \mathrm{~kg} \mathrm{caco}$.

**ME, metabolizable energy calculation based on NRC tables for sheep (1985).

Table 2: Lamb and ewe performance of control and treatment groups (means $\pm \mathrm{SE}$ )

\begin{tabular}{lccc}
\hline \multicolumn{1}{c}{ Item } & CG & TG & P \\
\hline Lamb performance & & & \\
Number of lambs/ewe & $1.5 \pm 0.17$ & $1.6 \pm 0.16$ & 0.67 \\
Lamb birth weight, kg & $3.99 \pm 0.05^{\mathrm{b}}$ & $4.47 \pm 0.03^{\mathrm{a}}$ & $<0.001$ \\
Lamb weight, kg (30 day post-lambing) & $10.77 \pm 0.04^{\mathrm{b}}$ & $12.53 \pm 0.06^{\mathrm{a}}$ & $<0.001$ \\
Total weight gain, kg & $6.78 \pm 0.06^{\mathrm{b}}$ & $8.06 \pm 0.07^{\mathrm{a}}$ & $<0.001$ \\
Daily weight gain, g & $226.00 \pm 1.84^{\mathrm{b}}$ & $268.66 \pm 2.28^{\mathrm{a}}$ & $<0.001$ \\
\hline Ewe performance & & & \\
DMI g/day (late pregnancy) & $1699.92 \pm 3.68$ & $1695.85 \pm 3.88$ & 0.46 \\
Ewe BW, kg (d 130 pregnancy) & $53.86 \pm 0.11$ & $54.02 \pm 0.09$ & 0.29 \\
Ewe BW, kg (d 140 pregnancy) & $54.86 \pm 0.12$ & $55.02 \pm 0.1$ & 0.30 \\
DMI g/day (early lactation) & $2296.74 \pm 6.02$ & $2303.38 \pm 5.60$ & 0.43 \\
BW after lambing (d 1) & $44.86 \pm 0.14^{\mathrm{b}}$ & $46.02 \pm 0.15^{\mathrm{a}}$ & $<0.001$ \\
BW after lambing (d 30) & $41.18 \pm 0.25^{\mathrm{b}}$ & $45.32 \pm 0.13^{\mathrm{a}}$ & $<0.001$ \\
Weight loss, kg & $-3.68 \pm 0.23$ & $-0.70 \pm 0.05$ & $<0.001$ \\
\hline
\end{tabular}

*Means bearing different superscript letters in the same raw differ significantly $(\mathrm{P}<0.05)$.

BW, body weight; DMI, dry matter intake; d, day 
Table 3: Activities of antioxidant enzymes and selenium concentrations of treated and control groups (means $\pm \mathrm{SE}$ )

\begin{tabular}{cccccc}
\hline & Group & TAC, $\mathbf{~ m m o l} / \mathbf{L}$ & GSH U/g Hb & MDA, $\boldsymbol{\mu \text { mol} / \mathbf { L }}$ & Selenium, umol/L \\
\hline \multirow{3}{*}{ Day 2} & CG & $42.33 \pm 3.28^{\mathrm{b}}$ & $206 \pm 1.73^{\mathrm{b}}$ & $15.44 \pm 0.18^{\mathrm{a}}$ & $0.96 \pm 0.04^{\mathrm{b}}$ \\
& TG & $73.81 \pm 3.26^{\mathrm{a}}$ & $312.24 \pm 9.8^{\mathrm{a}}$ & $14.27 \pm 0.09^{\mathrm{b}}$ & $1.74 \pm 0.05^{\mathrm{a}}$ \\
& P & 0.03 & 0.13 & 0.004 & $<0.001$ \\
\hline \multirow{3}{*}{ Day4 } & CG & $39.00 \pm 3.6^{\mathrm{b}}$ & $204.00 \pm 0.58^{\mathrm{b}}$ & $15.4 \pm 0.12^{\mathrm{a}}$ & $0.91 \pm 0.04^{\mathrm{b}}$ \\
& TG & $70.63 \pm 3.5^{\mathrm{a}}$ & $592.33 \pm 1.45^{\mathrm{a}}$ & $14.63 \pm 0.09$ & $1.71 \pm 0.02^{\mathrm{a}}$ \\
& P & 0.03 & $<0.001$ & 0.006 & 0.001 \\
\hline \multirow{3}{*}{ Day 14 } & CG & $70.91 \pm 5.75$ & $205.67 \pm 1.2^{\mathrm{b}}$ & $13.17 \pm 0.12^{\mathrm{a}}$ & $0.97 \pm 0.07^{\mathrm{b}}$ \\
& TG & $72.49 \pm 11.65$ & $593.00 \pm 1.53^{\mathrm{a}}$ & $11.90 \pm 0.26^{\mathrm{b}}$ & $1.72 \pm 0.04^{\mathrm{b}}$ \\
& P & 0.9 & $<0.001$ & 0.01 & 0.001 \\
\hline \multirow{3}{*}{ Day 17 } & CG & $70.91 \pm 5.75$ & $201.33 \pm 1.76^{\mathrm{b}}$ & $10.8 \pm 0.17^{\mathrm{a}}$ & $1.01 \pm 0.03^{\mathrm{b}}$ \\
& TG & $72.49 \pm 11.65$ & $594.21 \pm 8.17^{\mathrm{a}}$ & $9.53 \pm 0.22^{\mathrm{b}}$ & $1.75 \pm 0.05^{\mathrm{a}}$ \\
& P & 0.9 & 0.001 & 0.01 & $<0.001$ \\
\hline \multirow{3}{*}{ Day 20 } & CG & $70.91 \pm 5.75$ & $204.00 \pm 1.15^{\mathrm{b}}$ & $8.33 \pm 0.09^{\mathrm{a}}$ & $1.00 \pm 0.06^{\mathrm{b}}$ \\
& TG & $72.49 \pm 11.65$ & $595.33 \pm 0.88^{\mathrm{a}}$ & $7.7 \pm 0.06^{\mathrm{b}}$ & $1.84 \pm 0.02^{\mathrm{a}}$ \\
& P & 0.9 & $<0.001$ & 0.004 & $<0.001$ \\
\hline \multirow{3}{*}{ Day 25 } & CG & $70.91 \pm 5.75$ & $196.0 \pm 1.73^{\mathrm{b}}$ & $7.4 \pm 0.15^{\mathrm{a}}$ & $1.19 \pm 0.07^{\mathrm{b}}$ \\
& TG & $72.49 \pm 11.65$ & $563.33 \pm 1.76^{\mathrm{a}}$ & $6.73 \pm 0.09^{\mathrm{b}}$ & $3.48 \pm 0.26^{\mathrm{a}}$ \\
& P & 0.9 & $<0.001$ & 0.02 & 0.001 \\
\hline
\end{tabular}

*Means with different superscripts $(a, b)$ in the same column (for each day separately) differ significantly $(\mathrm{P}<0.05)$.

TAC, Total antioxidant capacity; MDA, Malondialdehyde; GSH, Glutathione peroxidase

Table 4: Mineral profile (ppm) of colostrum and milk of control and treatment groups (means $\pm \mathrm{SE}$ )

\begin{tabular}{|c|c|c|c|}
\hline Item & CG & TG & $\mathbf{P}$ \\
\hline \multicolumn{4}{|l|}{ Colostrum } \\
\hline $\mathrm{Cu}$, & $0.51 \pm 0.03^{b}$ & $0.94 \pm 0.09^{\mathrm{a}}$ & 0.01 \\
\hline $\mathrm{Se}$ & $0.08 \pm 0.003^{\mathrm{a}}$ & $0.17 \pm 0.001^{\mathrm{a}}$ & $<0.001$ \\
\hline $\mathrm{Zn}$ & $13.94 \pm 0.07^{\mathrm{a}}$ & $10.59 \pm 0.06^{\mathrm{b}}$ & 0.02 \\
\hline \multicolumn{4}{|l|}{ Milk } \\
\hline $\mathrm{Cu}$ & $0.49 \pm 0.05^{b}$ & $1.14 \pm 0.22^{\mathrm{a}}$ & 0.04 \\
\hline $\mathrm{Se}$ & $0.06 \pm 0.003^{b}$ & $0.13 \pm 0.02^{\mathrm{a}}$ & 0.02 \\
\hline $\mathrm{Zn}$ & $4.98 \pm 0.24^{\mathrm{a}}$ & $3.64 \pm 0.27^{\mathrm{b}}$ & 0.01 \\
\hline
\end{tabular}

*Means bearing different superscript letters in the same raw differ significantly $(\mathrm{P}<0.05)$

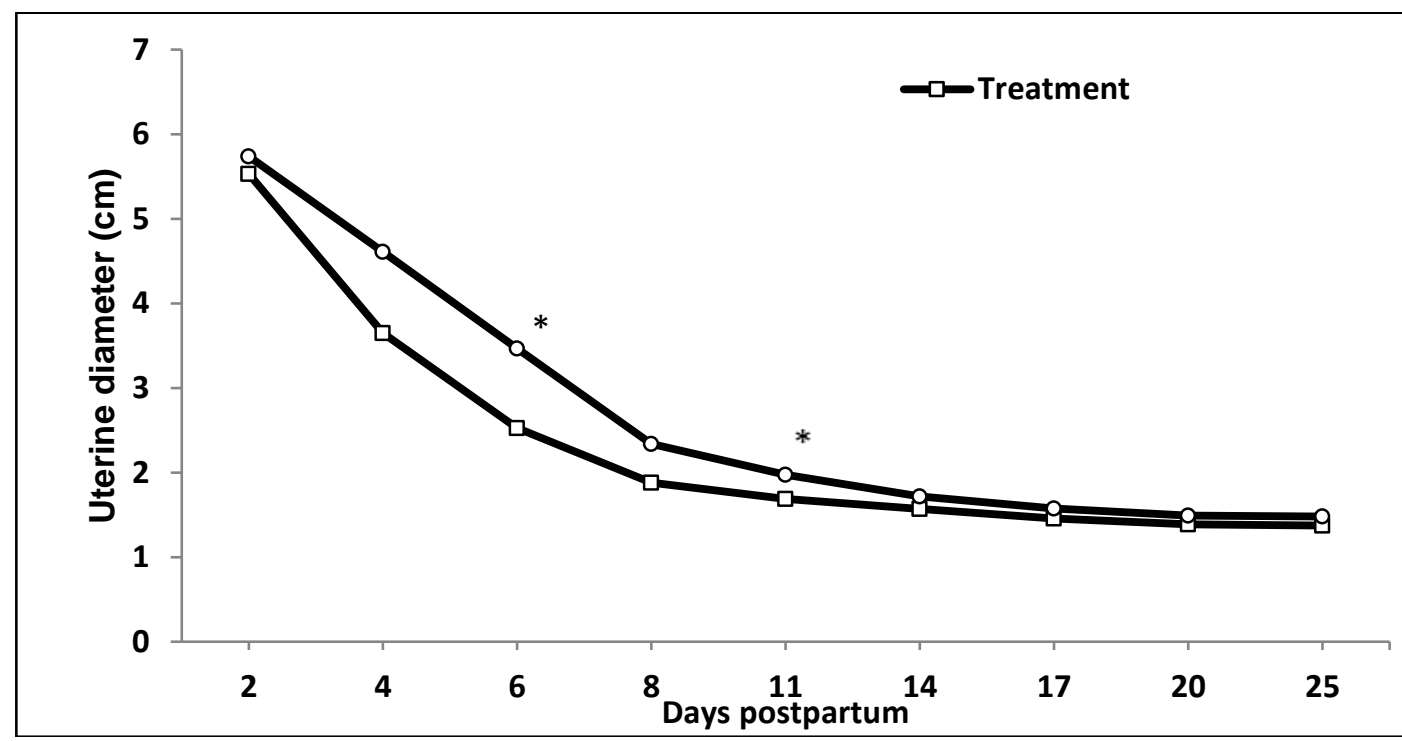

Figure 1: Pattern of uterine involution in treated and control group during postpartum period 

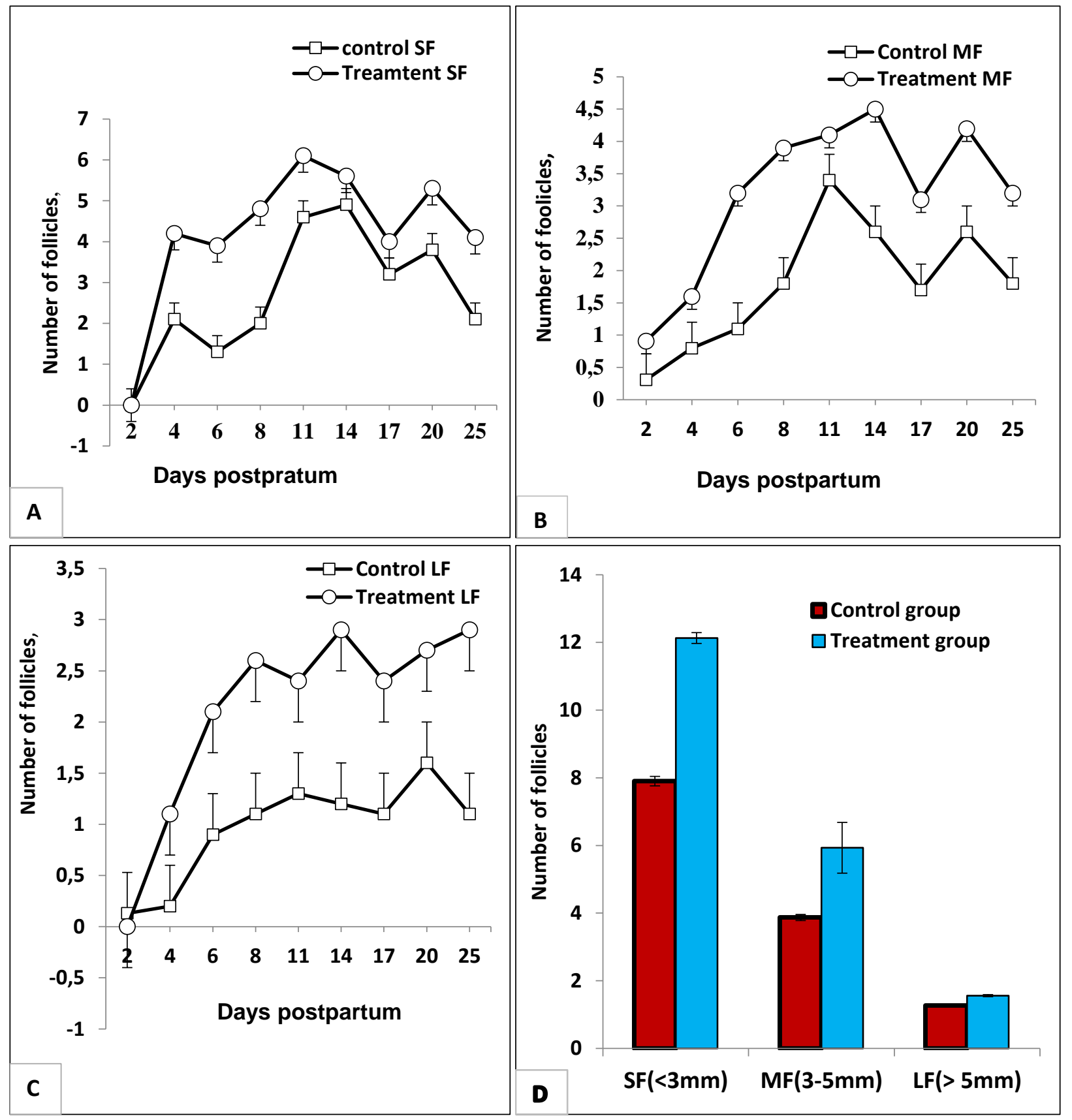

Figure 2: A, Number of small follicle (SF); B, medium follicle (MF); C, large follicle (LF); D, Overall number of small, medium and large follicles in treated and control ewes during postpartum period. Means are significantly different between groups in all parameters in comparison $(\mathrm{P}<0.05)$ 

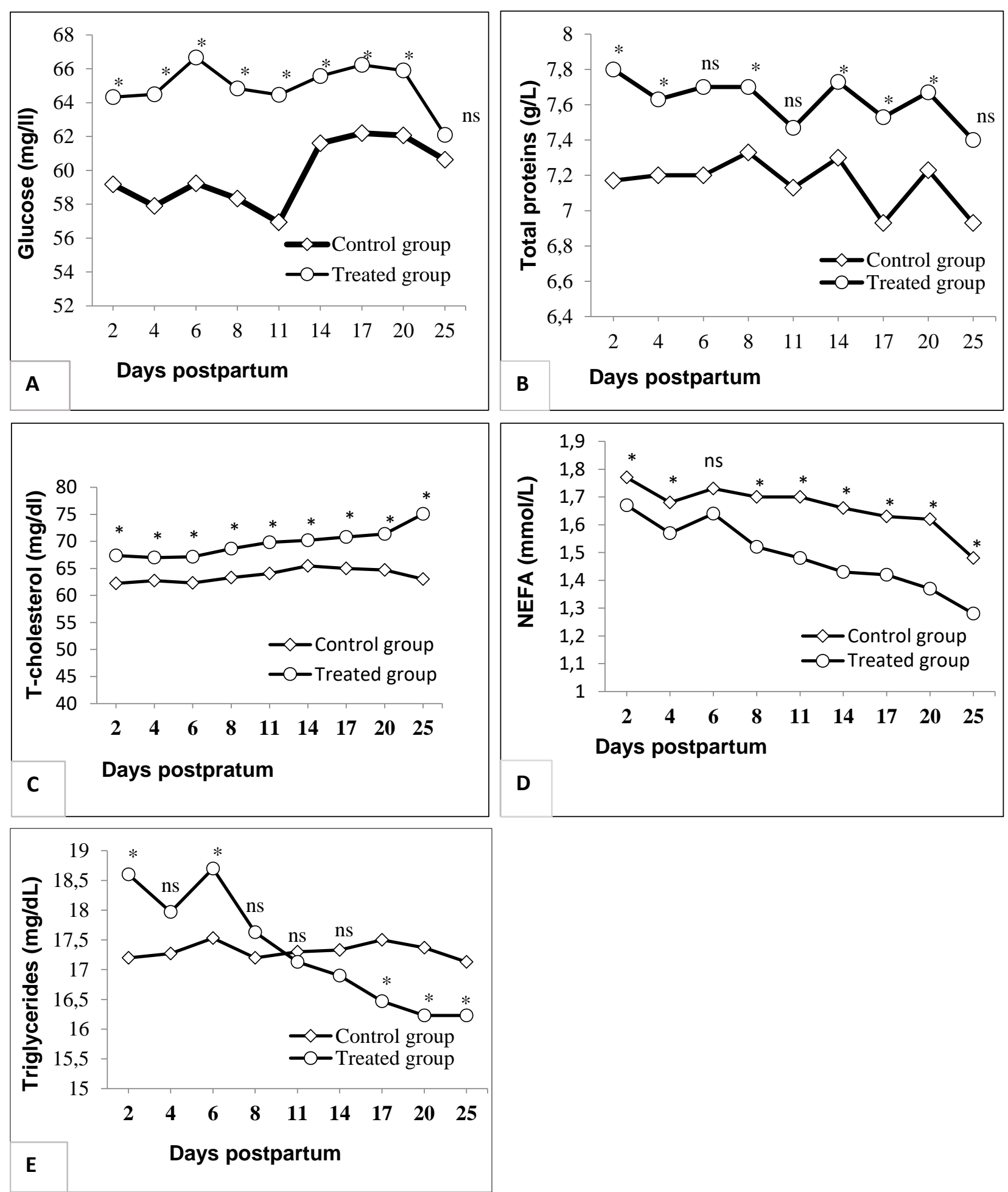

Figure 3: Concentration of blood glucose (A), total proteins (B), total cholesterol (C), non-esterified fatty acids, NEFA (D) and triglycerides (E) in control and treated group during postpartum period $(\mathrm{P}<0.05)$.

\section{Discussion}

Previous studies have suggested that supplementation with VE and Se can improve the function of the immune system, reproductive performance, and growth performance of goats and can increase the survival of Merino lambs $(1,5,16)$. The improved productivity of Ossimi ewes was consistent with the previous studies in terms of higher lamb numbers, heavier birth 
weight, and higher body weight gain on day 30 in the TG $(9,17)$. These studies showed that the supplementation or inclusion of VE and Se in the diet of the mother can improve the lamb performance. Lambs reared by ewes supplemented by $\mathrm{VE}$ and $\mathrm{Se}$ in the late gestation period showed better weight gain and heavier weaning weight. An explanation for that, VE and selenium supplementation increased their concentrations in colostrum and milk, which improve the immune function, feed efficiency and daily weight gain of suckling lambs $(18,19)$. The rate of uterine involution was significantly faster $(\mathrm{P}<0.05)$ in the TG in comparison to control ewes. This result is in agreement with the previous observations of Kiracofe (20) who reported that the diameter of uterine horns returned to their non-pregnant size by 21 days postpartum in ewes and that the uterus was similar in size to the non-pregnant uterus by the day 25 . The earlier first ovulation with large-sized ovulatory follicles with large numbers of small, medium, and large-sized follicles in the treated ewes indicated the earlier resumption of ovarian activity and agreed with the results of previous investigations $(9,21)$. The Role of VE in the development of follicles and ovarian activity is unknown, but ovulation-induced oxidative damage to the ovarian epithelium of ewes can be prevented by supplementation of VE (22). Selenium is important for formation of the selenoprotein glutathione peroxidase 1(GPx1) which plays an important role in female reproductive function; i.e., involved in determining the follicle growth, maturation, and dominance in both cows and women (23). Potential role of antioxidant like vitamin $\mathrm{E}$ and $\mathrm{Se}$ in follicle dominance are protecting the dominant follicle from increasing levels of reactive oxygen species (ROS) (23).

The significant increase of Se in serum and selenium and copper in colostrum, and milk is in agreement with earlier studies (24, 25). These previous studies indicated that VE and Se supplementation resulted in increasing the levels of VE and Se in the blood and consequently in the colostrum and milk of ewes during lactation.
On the other hand, significant differences $(\mathrm{P}<0.05)$ in blood biochemical parameters were observed between the TG and the CG. Ewes showed a significant increase $(\mathrm{P}<0.05)$ in the levels of plasma total protein, glucose, total cholesterol, and a low level of NEFA after VE plus Se supplementation during the late gestation and suckling periods. These results consistent with previous studies $(26,27)$. A higher level of glucose (relative to control ewes) following the supplementation of Se and VE was observed in previous studies $(28,29)$. Although, Se and VE directly affect the metabolism of carbohydrates, it is not clear whether increased glucose level directly or indirectly through increasing thyroxin and triiodothyronine hormones in supplemented animals as reported in previous studies (26). In the pregnant ewes, the increased concentrations of total protein and albumin following VE and Se supplementation were reported by previous studies $(28,29)$. The exact mechanism that leads to a higher total protein in the serum of the TG was not elucidated in these studies but increased concentrations of $\gamma$ globulin could be a part of the mechanism. Another supporting research to our findings reported that the concentration of blood metabolites and the total antioxidant status in plasma were elevated in sheep received Se and VE supplements $(27,30)$. In this study, significant increase of GSH-Px and TAC was noticed after VE and Se supplementation compared with the control. This indicates that the maternal supplementation of Se and VE during late pregnancy and early lactation can improve the antioxidant status of Ossimi ewes.

The increased levels of NEFA in CG were nearly similar with the findings observed by Avci and Kizil (31) in transition cows and are indicative of the increasing depletion of lipid reserves existed because of the increased energy demand. Also, the increased NEFA in the $\mathrm{CG}$ indicates the utilization of fat storage reserves to meet the rapid and dramatic energy responses in the ewes of this group. It can therefore be assumed that VE and Se supplementation may improve the energy balance in lactating ewes and decrease the weight loss during lactation. 


\section{Conclusion}

Supplementation of pregnant ewes with VE and selenium (two weeks pre and post-lambing) had a significant effect $(\mathrm{P}<0.05)$ on the postpartum reproductive performance of ewes in terms of higher uterine involution, earlier ovarian resumption and first ovulation with large size ovulatory follicle, higher numbers of small, medium and large sized follicles. Furthermore, VE and Se supplementation had improved ewe and lamb performance, colostrum and milk mineral profiles, the metabolic and antioxidant status of Ossimi ewes. In conclusion, during the periods of late gestation and early lactation, VE and Se supplementation could be considered an effective strategy for minimizing the weight loss of ewes, enhancing lamb performance, the antioxidant and metabolic status, which improves the reproductive performance of Ossimi ewes.

\section{Conflict of interest}

The authors declare that they have no conflict of interest

\section{Acknowledgments}

The authors would like to thank the staff of the Research and Production farm, Department of Animal Production, Faculty of Agriculture, Assiut University for their support and help during running the experiment.

\section{Author contributions}

S. M. A. designed the experiment, shared in running the experiment, sample collection and analysis, carry out statistical analysis of the data and wrote the manuscript. G.B. M. shared in running the experiment, sample collection and analysis and shared in revising the manuscript. W.S. shared in running the experiment, writing and revising the manuscript. T. M. E shared in sample collection, performed ultrasound measurements and revised the manuscript. All authors read and approved the final manuscript.

\section{References}

1. Sterndale S, Broomfield S, Currie A, Hancock S, Kearney GA, Lei J, Liu S, Lockwood A, Scanlan V, Smith G, Thompson AN. Supplementation of Merino ewes with vitamin E plus selenium increases $\alpha$-tocopherol and selenium concentrations in plasma of the lamb but does not improve their immune function. Animal 2018; 12(5):998-1006.

2. Harrison JH, Hancock DD, Conrad HR. Vitamin E and Selenium for Reproduction of the Dairy Cow1, 2. Journal of Dairy Science 1984; 67(1):12332.

3. Pieczyńska J, Grajeta H. The role of selenium in human conception and pregnancy. Journal of Trace Elements in Medicine and Biology 2015; 29:31-8.

4. Scherf H, Machlin LJ, Frye TM, Krautmann BA, Williams SN. Vitamin E biopotency: Comparison of various 'natural-derived'and chemically synthesized $\alpha$-tocopherols. Animal Feed Science and Technology 1996; 59(1-3):115-26.

5. Aghwan ZA, Sazili AQ, Kadhim KK, Alimon AR, Goh YM, Adeyemi KD. Effects of dietary supplementation of selenium and iodine on growth performance, carcass characteristics and histology of thyroid gland in goats. Animal Science Journal 2016; 87(5):690-6.

6. Maraba KP, Mlambo V, Yusuf AO, Marume U, Hugo A. Extra dietary vitamin E-selenium as a mitigation strategy against housing-induced stress in Dohne Merino lambs: Effect on growth performance, stress biomarkers, and meat quality. Small Ruminant Research 2018; 160:31-7.

7. McDowell LR, Williams SN, Hidiroglou N, Njeru CA, Hill GM, Ochoa L, Wilkinson NS. Vitamin E supplementation for the ruminant. Animal Feed Science and Technology 1996; 60(3-4):27396.

8. Kott RW, Thomas VM, Hatfield PG, Evans T, Davis KC. Effects of dietary vitamin E supplementation during late pregnancy on lamb mortality and ewe productivity. Journal of the American Veterinary Medical Association. 1998; 212(7):997-1000.

9. Koyuncu M, Yerlikaya H. Short Communication Effect of selenium-vitamin E injections of ewes on reproduction and growth of their lambs. South African Journal of Animal Science 2007;37(4):2336.

10. NRC, National Research Council (US). Nutrient requirements of sheep. Sixth revised Edition, The National Academy Press, Washington, DC, 1985: 99.

11. NRC, National Research Council (US), Nutrient Requirements of Small Ruminants: Sheep, Goats, Cervids, and New World Camelids", The National Academies Press, Washington, DC", 2007.

12. El-Bahr SM, Abdelghany A. Heavy metal and trace element contents in edible muscle of three commercial fish species, and assessment of possible risks associated with their human consumption in 
Saudi Arabia. Journal of Advanced Veterinary and Animal Research. 2015; 2(3):271-8.

13. AOAC. f International. 16th ed., vol. 1 (Cunnif, P. Ed.), AOAC Int., Arlington, Virginia, USA., 1995.

14. Meligy AM. Comparative study of element contents in seven isolates of entomopathogenic nematodes. Egyptian Journal of Biological Pest Control 2018; 28(1):1.

15. SPSS. Statistical Packages for the Social Sciences. Statistical software for windows version 16.0, Microsoft, Chicago, IL., USA, 2007.

16. Song YX, Hou JX, Zhang L, Wang JG, Liu $\mathrm{XR}$, Zhou ZQ, Cao BY. Effect of dietary selenomethionine supplementation on growth performance, tissue Se concentration, and blood glutathione peroxidase activity in kid boer goats. Biological Trace element Research 2015; 167(2):242-50.

17. Rosales Nieto CA, Meza-Herrera CA, Cedillo FD, Najera MD, Vázquez HG, Pérez FD, Liu S. Vitamin E supplementation of undernourished ewes pre-and post-lambing reduces weight loss of ewes and increases weight of lambs. Tropical Animal Health and Production 2016; 48(3):613-8.

18. Macit M, Aksakal V, Emsen E, Esenbuğa N, Aksu MI. Effects of vitamin E supplementation on fattening performance, non-carcass components and retail cut percentages, and meat quality traits of Awassi lambs. Meat Science 2003 May 1; 64(1): $1-6$.

19. Moeini MM, Jalilian MT. Effect of selenium and vitamin $\mathrm{E}$ injection during late pregnancy on im- mune system and productive performances of Sanjabi ewes and their lambs. Global Journal of Animal Scientific Research 2014; 2(3):210-9.

20. Kiracofe GH. Uterine involution: its role in regulating postpartum intervals. Journal of Animal Science. 1980; 51(suppl II):16-28.

21. Musa SI, Bitto II, Ayoade JA, Oyedipe OE. Effects of Vitamin E and Selenium on Fertility and Lamb Performance of Yankasa Sheep. Open Journal of Veterinary Medicine 2018; 8(09):167-73.

22. Murdoch WJ, Martinchick JF. Oxidative damage to DNA of ovarian surface epithelial cells affected by ovulation: carcinogenic implication and chemoprevention. Experimental Biology and Medicine 2004; 229(6):546-52.

23. Ceko MJ, Hummitzsch K, Hatzirodos N, Bonner WM, Aitken JB, Russell DL, Lane M, Rodgers RJ, Harris HH. X-Ray fluorescence imaging and other analyses identify selenium and GPX1 as important in female reproductive function. Metallomics 2014; 7(1):71-82.
24. Capper JL, Wilkinson RG, Kasapidou E, Pattinson SE, Mackenzie AM, Sinclair LA. The effect of dietary vitamin E and fatty acid supplementation of pregnant and lactating ewes on placental and mammary transfer of vitamin $E$ to the lamb. British Journal of Nutrition. 2005; 93(4):549-57.

25. Jalilian MT, Moeini MM, Karkodi K. Effect of selenium and vitamin E supplementation during late pregnancy on colostrum and plasma $\mathrm{Se}, \mathrm{Cu}, \mathrm{Zn}$ and $\mathrm{Fe}$ concentrations of fat tail Sanjabi ewes and their lambs. Acta Agriculturae Slovenica (Slovenia). 2012; 100(2): 125-9.

26. Mohri M, Ehsani A, Norouzian MA, Bami MH, Seifi HA. Parenteral selenium and vitamin E supplementation to lambs: hematology, serum biochemistry, performance, and relationship with other trace elements. Biological Trace Element Research 2011; 139(3):308-16.

27. Shi L, Ren Y, Zhang C, Yue W, Lei F. Effects of maternal dietary selenium (Se-enriched yeast) on growth performance, antioxidant status and haemato-biochemical parameters of their male kids in Taihang Black Goats. Animal Feed Science and Technology 2017; 231:67-75.

28. Pisek L, Travnicek J, Salat J, Kroupova V, Soch M. Changes in white blood cells in sheep blood during selenium supplementation. Veterinarni Medicina Praha 2008; 53(5):255.

29. Avci M, Karakilçik Z, Kanat R. Effects of vitamins $\mathrm{A}, \mathrm{E}$ and selenium on reproductive performance and serum levels of some biochemical parameters in ewes, and birth weight and survival rates in their lambs. Turkish Journal of Veterinary And Animal Sciences 2000; 24(1):45-50.

30. Alhidary IA, Shini S, Al Jassim RA, Abudabos AM, Gaughan JB. Effects of selenium and vitamin $\mathrm{E}$ on performance, physiological response, and selenium balance in heat-stressed sheep. Journal of Animal Science 2015; 93(2):576-88.

31. Avc1 C, Kizil O. The effects of injectable trace elements on metabolic parameters in transition cow. Kafkas Üniversitesi Veteriner Fakültesi Dergisi 2013; 19 (Supplement A) ): A73-8. 